\title{
Influência do Processamento Acelerado de Presunto Cru Na Redução da Atividade de Água.
}

Ítalo Abreu LIma (I), Hewerton Barbosa Gomes (I), Carolina Naves Aroeira (I), Douglas Roberto Guimarães da Silva (I), Henrique Pereira Cazedey (I), Alcinéia de Lemos Souza Ramos (I), Eduardo Mendes Ramos (I)

(I) UFLA - Universidade Federal de Lavras (Caixa Postal 3037)

\section{Resumo}

Um dos principais fatores a serem considerados na conservação de presunto cru, é a atividade de água que promove a inibição de microrganismos indesejáveis, como os deterioradores e patogênicos. $\mathrm{O}$ objetivo do trabalho foi avaliar a redução da atividade de água e acompanhar a perda de peso durante o processamento de presunto cru obtido do pernil dianteiro de suíno. Os produtos foram elaborados pela aplicação de salga a seco no pernil desossado. As peças cárneas foram então adicionadas aos ingredientes: sal, açúcar, nitrito, nitrato, GDL e transglutaminase. Foram elaborados dois produtos, o Tratamento 1 (T1) sem adição de lactulose e Tratamento 2 (T2) com adição de lactulose. Os pedaços cárneos foram acomodadas em formas plásticas e mantidos sob refrigeração $\left(4^{\circ} \mathrm{C}\right)$ por 48 horas, para equalização. Em seguida foram removidos das formas, e levados para $\operatorname{BOD}\left(4,0^{\circ} \mathrm{C}\right)$, por quatro dias, para uma pré-secagem. Após este período, as peças ficaram sob condições de temperatura $\left(16^{\circ} \mathrm{C}\right)$ e umidade relativa $(75-80 \% \mathrm{UR})$ controladas, para a maturação/secagem. A determinação da atividade de água (Aa) dos produtos foi realizada por meio do aparelho da Aqualab Química e foram realizadas ao longo do processamento que teve uma duração de 30 dias. A perda de peso foi acompanhada durante o período de maturação em intervalos de 3 dias. Houve uma redução significativa tanto na Aa como na 
perda de peso em ambos tratamentos. No T1, o valor inicial de atividade de água foi de 0,97 no tempo 0 . Esse valor foi reduzindo a medida que o presunto ia perdendo peso : 0,$95 ; 0,91$ e 0,89 ao longo dos tempos 1,2 e 3 (20\%, 30\% e $40 \%$ de perda de peso) respectivamente. O mesmo ocorreu no T2, no tempo 0. Houve uma diminuição da Aa de 0,96 para 0,89 quando o produto chegou à fase final com $40 \%$ de perda de peso. A Instrução Normativa $\mathrm{n}^{\circ} 22$, de 31 de julho de 2000 do Ministério da Agricultura e do Abastecimento, para presunto cru indica que o mesmo deve apresentar atividade de água máxima de 0,92. A vida útil dos alimentos pode ser estimado através da avaliação do valor da atividade de água no mesmo. Os valores encontrados para atividade de água nesse trabalho se encontram abaixo do valor recomendado, sendo os produtos considerados estáveis e, portanto, podem ser armazenados sem refrigeração.

Palavras-Chave: Carne suína, Perda de peso, Atividade de água, Presunto Agência de Fomento: FAPEMIG (Fundação de Amparo à Pesquisa do estado de Minas Gerais) 